\title{
Actinidin from kiwifruit (Actinidia deliciosa cv. Hayward) increases the digestion and rate of gastric emptying of meat proteins in the growing pig
}

\author{
Carlos A. Montoya ${ }^{1 *}$, Shane M. Rutherfurd ${ }^{1}$, Trent D. Olson ${ }^{1}$, Ajitpal S. Purba ${ }^{1}$, Lynley N. Drummond ${ }^{2}$, \\ Mike J. Boland ${ }^{1}$ and Paul J. Moughan ${ }^{1}$ \\ ${ }^{1}$ Riddet Institute, Massey University, Private Bag 11222, Palmerston North, New Zealand \\ ${ }^{2}$ ZESPRI International Limited, Mount Maunganui, New Zealand
}

(Submitted 30 January 2013 - Final revision received 18 September 2013 - Accepted 22 September 2013 - First published online 19 November 2013 )

\section{Abstract}

The present study aimed to investigate the effect of dietary actinidin on the kinetics of gastric digestion of beef muscle proteins and on the rate of stomach emptying in growing pigs. For this purpose, 120 pigs (mean body weight 28 (sD 2.9) kg) were fed beef muscle proteinbased diets containing either actinidin (fresh green kiwifruit pulp or gold kiwifruit pulp supplemented with purified actinidin) or no actinidin (fresh gold kiwifruit pulp or green kiwifruit pulp with inactivated actinidin). Additionally, fifteen pigs were fed with a protein-free diet to determine the endogenous protein flow. Pigs were euthanised at exactly $0 \cdot 5,1,3,5$ and 7 h postprandially ( $n 6$ per time point for each kiwifruit diet and $n 3$ for protein-free diet). Stomach chyme was collected for measuring gastric retention, actinidin activity, individual beef muscle protein digestion based on SDS-PAGE and the degree of hydrolysis based on the appearance of free amino groups. The stomach emptying of DM and $\mathrm{N}$ was faster when actinidin was present in the diet $(P<0 \cdot 05)$ : the half gastric emptying time of DM was $137 v .172 \mathrm{~min}( \pm 7.4 \mathrm{~min}$ pooled standard error) for the diets with and without actinidin, respectively. The presence of dietary actinidin in the stomach chyme increased the digestion of beef muscle protein $(P<0.05)$ and, more specifically, those proteins with a high molecular weight $(>34 \mathrm{kDa} ; P<0.05)$. In conclusion, dietary actinidin fed in the form of fresh green kiwifruit increased the rate of gastric emptying and the digestion of several beef muscle proteins.

\section{Key words: Actinidin: Beef muscle proteins: Stomach emptying rates: Gastric digestion: Growing pigs}

Actinidin is a cysteine protease present at high levels ( $284 \mu \mathrm{mol}-\mathrm{o}$-nitrophenol/min per $\mathrm{g} \mathrm{DM}$ ) in several varieties of kiwifruit, including 'green' kiwifruit (Actinidia deliciosa cv. 'Hayward'), but is not present in 'gold' kiwifruit (Actinidia chinensis cv. 'Hort16A'). Although the function of actinidin is unknown, it has been suggested that actinidin acts as a pathogen defence and assists in the ripening of kiwifruit ${ }^{(1)}$. Dietary actinidin from kiwifruit affects gastric protein digestion. Kaur et $a l^{(2)}$, using an in vitro model of gastric digestion, showed that actinidin (in the form of a green kiwifruit extract) increased the extent and rate of gastric digestion of several proteins (casein, soya protein isolate and beef muscle). Moreover, Rutherfurd et al. ${ }^{(3)}$, using an in vivo rat model, showed that dietary actinidin (in the form of freeze-dried whole kiwifruit) increased the extent of gastric digestion of several protein sources, including soya protein isolate, beef muscle, gelatin and gluten. To date, however, there is no information available describing the effect of actinidin or of green kiwifruit on the kinetics of gastric digestion for different food proteins.
Previous studies have suggested that the rate and the extent of gastric digestion of dietary proteins may modulate the stomach emptying rate $(\mathrm{SER})^{(4-7)}$. Furthermore, altering the SER may influence the rate of digestion and absorption of food nutrients $^{(4,8)}$. If actinidin increases the rate at which proteins are digested and are thus emptied from the stomach, it may play a role in the digestion and absorption of dietary proteins and other nutrients overall. There is no information, however, as to whether an increase in gastric protein digestion observed in the presence of dietary actinidin influences the SER.

In the present study, it was hypothesised that actinidin would increase the rate of gastric digestion of dietary proteins and that this would in turn modulate the SER of proteins. Consequently, the present study aimed to explore the effect of dietary actinidin (supplied in the form of fresh green kiwifruit) on the kinetics of gastric digestion and the SER of a beef muscle protein source. The growing pig was used as a model for adult humans ${ }^{(9)}$ and beef muscle protein was chosen as a model protein, as previous studies in our

Abbreviations: ADU, arbitrary density units; BI, band intensity; BW, body weight; MHC, myosin heavy chain; MLC, myosin light chain; MW, molecular weight; SER, stomach emptying rate; $T_{1 / 2}$, half gastric emptying time; $\mathrm{TD}_{50}$, half of the gastric disappearance time. 
laboratory, based on a rat model, have shown that actinidin can affect the gastric digestion of some beef muscle proteins and also that anecdotally consuming diets high in meat has been associated with gastric discomfort.

\section{Experimental methods}

\section{Dietary treatments}

A basal diet, a protein-free diet (used to determine the endogenous proteins present in the stomach chyme) and four semi-synthetic experimental diets containing beef muscle protein as the sole source of protein and either green (Hayward) or gold (Hort16A) kiwifruit were formulated (Table 1). The quantity of fresh kiwifruit included in the diets was calculated with reference to the prescribed daily food intake for an adult human (approximately $500 \mathrm{~g}$ $\mathrm{DM})^{(10)}$, to provide an intake equivalent of consuming two kiwifruit with an average-sized meal ${ }^{(2)}$; thus, kiwifruit represented $20 \%$ of the daily DM intake. Beef muscle was prepared by grinding freeze-dried and minced low-fat beef steak through a $1 \mathrm{~mm}$ mesh.

A. chinensis cv. 'Hort16A' (gold kiwifruit) was chosen as an actinidin-negative control, as it is almost devoid of actinidin activity $^{(11)}$ (gold kiwifruit negative control). Although the chemical composition and microstructure of gold kiwifruit is similar to that of green kiwifruit (A. deliciosa cv. Hayward), they are not identical ( 7 and 5\% crude protein, 13 and $17 \%$ total dietary fibre, 4 and $3 \%$ starch, 3 and $5 \%$ total lipids and 4 and $4 \%$ minerals for gold and green kiwifruit, respectively) $)^{(12)}$. Thus, a second negative control was used; green kiwifruit in which actinidin was chemically inactivated (green kiwifruit negative control). A test diet (green kiwifruit test diet) containing fresh green kiwifruit pulp was also prepared along with a positive control diet (gold kiwifruit positive control) containing gold kiwifruit pulp to which purified actinidin (New Zealand Pharmaceuticals Limited) was added such that the actinidin activity was the same as in the test diet. For the green kiwifruit negative control, actinidin was inactivated using $\mathrm{H}_{2} \mathrm{O}_{2}\left(30 \%, 15 \mu \mathrm{l} \mathrm{H}_{2} \mathrm{O}_{2} / \mathrm{g}\right.$ of blended green kiwifruit pulp), to oxidise the sulfhydryl groups of cysteine proteases ${ }^{(13)}$. The concentration of $\mathrm{H}_{2} \mathrm{O}_{2}$ was lower than that suggested for the Food and Drug Administration security range (up to $3 \%)^{(14)}$, and well below the toxic level for pigs $(0.13 v .6 .7 \mathrm{~g} / \mathrm{kg}$ body weight (BW), Material Safety Data Sheet ${ }^{(15)}$. The diets were formulated to meet the nutrient requirements of the growing pig, as prescribed by the National Research Council ${ }^{(16)}$, for all nutrients, except protein in the protein-free diet. Titanium dioxide was added to the experimental diets as an indigestible marker. The daily ration was calculated as $90 \mathrm{~g} \mathrm{DM} / \mathrm{kg}$ metabolic BW $\left(\mathrm{BW}^{0.75}\right)$ per $\mathrm{d}$, and was fed to the pigs as two equal meals given at 09.00 and 16.00 hours. The fresh kiwifruit were peeled and crushed. The other ingredients and fresh kiwifruit were then thoroughly mixed immediately before the feeding of each pig. Simultaneously, purified actinidin was added to the gold kiwifruit positive control diet and mixed thoroughly. For the green kiwifruit negative control diet, actinidin in the green kiwifruit pulp was inactivated, as described above, $12 \mathrm{~h}$ before being added to the diets.

Table 1. Ingredient and nutrient compositions of the experimental diets ( $\mathrm{g} / \mathrm{kg} \mathrm{DM})$

\begin{tabular}{|c|c|c|c|c|c|c|}
\hline & \multirow[b]{2}{*}{ Basal } & \multicolumn{2}{|c|}{ Green kiwifruit } & \multicolumn{2}{|c|}{ Gold kiwifruit } & \multirow[b]{2}{*}{ Protein-free diet } \\
\hline & & Test $^{\star}$ & Negative control† & Positive controlł & Negative control & \\
\hline \multicolumn{7}{|l|}{ Ingredients } \\
\hline Green kiwifruit§ & - & 200 & 200 & - & - & - \\
\hline Gold kiwifruit§ & - & - & - & 200 & 200 & - \\
\hline Casein & 156 & - & - & - & - & - \\
\hline Meat protein\| & - & 138 & 138 & 138 & 138 & - \\
\hline Soyabean oil & 50 & 50 & 50 & 50 & 50 & 50 \\
\hline Sucrose & 106 & - & - & - & - & 106 \\
\hline Vitamin/mineral premix & 5 & 5 & 5 & 5 & 5 & 5 \\
\hline Cellulose & 51 & 13 & 13 & 13 & 13 & 51 \\
\hline $\mathrm{NaCl}$ & 3 & 3 & 3 & 3 & 3 & 3 \\
\hline Calcium bicarbonate & 1 & 2 & 2 & 2 & 2 & 1 \\
\hline Dicalcium phosphate & 20 & 17 & 17 & 17 & 17 & 20 \\
\hline Wheat starch & 605 & 569 & 569 & 542 & 569 & 761 \\
\hline Purified actinidin & - & - & - & 27 & - & - \\
\hline Titanium dioxide & 3 & 3 & 3 & 3 & 3 & 3 \\
\hline \multicolumn{7}{|c|}{ Determined nutrient and energy content } \\
\hline Crude protein & - & 126 & 122 & 132 & 125 & $1 \cdot 3$ \\
\hline Ash & - & 37 & 38 & 37 & 39 & 21 \\
\hline Total dietary fibre & - & 73 & 67 & 61 & 60 & 65 \\
\hline Energy (MJ/kg DM) & - & $19 \cdot 0$ & $19 \cdot 1$ & $18 \cdot 9$ & $18 \cdot 9$ & $17 \cdot 6$ \\
\hline
\end{tabular}

* In the green kiwifruit test diet, the green kiwifruit contained $284 \mu \mathrm{mol}-\mathrm{o}$-nitrophenol/min per $\mathrm{g}$ DM of actinidin activity.

$\dagger$ In the green kiwifruit negative control diet, actinidin present in the green kiwifruit was inactivated with $15 \mu \mathrm{l} \mathrm{H}_{2} \mathrm{O}_{2} / \mathrm{g}$ of fresh green kiwifruit pulp.

$\ddagger$ The actinidin activity of the purified actinidin was $2154 \mu \mathrm{mol}-\mathrm{o}$-nitrophenol/min per $\mathrm{g} \mathrm{DM}$, and was added to the gold kiwifruit positive control diet to supply the same actinidin activity as in the green kiwifruit test diet.

$\S$ The green and gold kiwifruit pulp was prepared fresh and added to the diets just before each meal.

|| Meat protein was prepared by freeze-drying low-fat beef steak and then by grinding, as described in the Experimental methods section.

I Vitamin/mineral mix was formulated to meet the requirements for vitamins and minerals as described by the National Research Council ${ }^{(16)}$. 


\section{Experimental design}

Ethics approval for the animal trials was obtained from the Animal Ethics Committee, Massey University, Palmerston North, New Zealand. A total of 135 entire male pigs (PIC Camborough $46 \times$ PICboar 356L, 28 (SD 2.9) kg BW) were used in the study. Pigs were kept individually in metabolism crates in a room maintained at $21 \pm 2^{\circ} \mathrm{C}$ with a $10 \mathrm{~h}$ light$14 \mathrm{~h}$ dark cycle. Pigs were adapted to their environment and diet (basal diet) for $10 \mathrm{~d}$. On the 11th day, pigs were allocated to one of the four experimental diets (green kiwifruit test, green kiwifruit negative control, gold kiwifruit positive control and gold kiwifruit negative control ( $n 30$ per dietary group constituting five time points $\times$ six pigs per time point)) or the protein-free diet ( $n$ 15, five time points $\times$ three pigs per time point). On the 13th day, water was withheld from the pigs for $2 \mathrm{~h}$ before each animal received a single meal at 09.00 hours, consisting of one half of its daily ration $\left(45 \mathrm{~g} \mathrm{DM} / \mathrm{kg} \mathrm{BW}^{0.75}\right)$. At $0.5,1,3,5$ and $7 \mathrm{~h}$ after the start of feeding, the pigs were anaesthetised with an intramuscular injection of an anaesthetic cocktail $(0.04 \mathrm{ml} / \mathrm{kg}$ BW of Zoletil $100(50 \mathrm{mg} / \mathrm{ml})$, Ketamine $(50 \mathrm{mg} / \mathrm{ml})$ and Xylazine $(50 \mathrm{mg} /$ $\mathrm{ml})$; Provet). Immediately after sedation, the pigs were euthanised by an intra-cardial injection of sodium pentobarbitone $(0.3 \mathrm{ml} / \mathrm{kg} \mathrm{BW}$ of Pentobarb 300; Provet). The stomach was immediately dissected out, and contents were collected, weighed and thoroughly mixed. A representative aliquot of chyme was taken, frozen at $-20^{\circ} \mathrm{C}$ and freeze-dried before chemical analysis. Additionally, approximately $0.5 \mathrm{~g}$ of each stomach chyme and diet sample were collected into Eppendorf tubes containing $1 \mathrm{ml}$ of $0.05 \mathrm{M}$-phosphate buffer solution and $0.4 \mathrm{M}$-sodium metabisulphite for the determination of actinidin activity. From the pigs fed the diets containing kiwifruit on the final day, only one of the pigs fed the gold kiwifruit positive control diet and euthanised at $0.5 \mathrm{~h}$ did not eat all of the diet (the pig consumed $89 \%$ of the offered diet). For this pig, the feed refusal was collected, dried and weighed to enable the calculation of the SER.

\section{Chemical analysis}

The diets were analysed in duplicate for DM (method $\left.930.15^{(17)}\right)$, protein $(\mathrm{N} \times 6 \cdot 25$, method 968.06 using a LECO elemental analyser; LECO Corporation), ash (method 942.05 using a muffle furnace at $500^{\circ} \mathrm{C}$ ), gross energy (LECO AC-350 Automatic Calorimeter; LECO Corporation), total dietary fibre ${ }^{(18)}$ and titanium dioxide ${ }^{(19)}$. Stomach chyme was analysed for DM, N and titanium dioxide as described above.

\section{Actinidin activity}

The kiwifruit pulp was mixed and manually homogenised at $4{ }^{\circ} \mathrm{C}$ in $0.05 \mathrm{M}$-phosphate buffer solution ( $\mathrm{pH}$ 6) containing $0.4 \mathrm{M}$ sodium metabisulphite $(5.6 \mathrm{~g} / \mathrm{ml})$ to avoid enzyme oxidation before being filtered through muslin cloth. The same phosphate buffer solution was also mixed with purified actinidin $(5 \mathrm{mg} /$ $\mathrm{ml}$ ), the green and gold kiwifruit diets and stomach chyme (approximately $0.5 \mathrm{~g} / \mathrm{ml}$ ). Each of the above preparations was centrifuged at $13000 \mathrm{~g}$ for $30 \mathrm{~min}$ at $4^{\circ} \mathrm{C}$. The supernatants were collected, and actinidin activity was measured as described previously ${ }^{(20)}$. Briefly, $100 \mu \mathrm{l}$ of the substrate Cbz-LLys-O-nitrophenol hydrochloride $(1.2 \mathrm{~g} / \mathrm{l}$ of deionised distilled water, Sigma; Sigma-Aldrich Pty Limited) were added to $2.85 \mathrm{ml}$ of phosphate buffer solution $(0.05 \mathrm{M}, \mathrm{pH} 6.0)$ directly in a spectrophotometer cuvette. No spontaneous breakdown of the substrate was observed. Then, $50 \mu$ l of a mixture containing the actinidin solution and $0 \cdot 1 \mathrm{M}$-dithioerythritol $(1: 1, \mathrm{v} / \mathrm{v})$ were added. The rate of change in absorbance was measured at $348 \mathrm{~nm}$ using a spectrophotometer.

\section{Total degree of protein hydrolysis}

Total degree of protein hydrolysis was determined as the increase in the concentration of free amino groups in the chyme samples, and was analysed using the $o$-phthaldialdehyde $\operatorname{method}^{(21)}$. Proteins were extracted from the chyme samples after mixing with sodium tetraborate buffer $(12.5 \mathrm{~mm}$ and $2 \%$ SDS) for $1 \mathrm{~h}$ at room temperature (10 $\mathrm{mg}$ sample/ml buffer). The extracted proteins were mixed with the $o$-phthaldialdehyde solution $(0 \cdot 1: 1, \mathrm{v} / \mathrm{v})$ and left to stand for $2 \mathrm{~min}$ before reading the absorbance at $340 \mathrm{~nm}$. The total amino groups in the diets were determined after acid hydrolysis with $6 \mathrm{M}-\mathrm{HCl}$ for $24 \mathrm{~h}$ at $110^{\circ} \mathrm{C}$. Then, $\mathrm{HCl}$ was removed using a centrifugal concentrator and replaced by sodium tetraborate buffer to measure the amino groups as described above.

\section{Electrophoresis analysis (SDS-PAGE)}

Tricine SDS-PAGE analysis was carried out as described by Rutherfurd et $a l^{(3)}$. The measurement of intact proteins and peptides stained with Coomassie Brilliant Blue R was carried out using gel scanning densitometry (Molecular Imager Gel Doc XR; Bio-Rad) followed by analysis using Quantity One 1-D Analysis software (Bio-Rad). Staining density was measured (in arbitrary density units (ADU)) horizontally for each protein band. Samples of the stomach chyme from pigs fed the protein-free diet were run on separate gels, and the ADU at the same MW of the dietary proteins were used to correct for endogenous proteins. In addition, the MW of each protein band was determined from the MW standards run in each gel, using Quantity One 1-D Analysis software (Bio-Rad).

\section{Calculations and statistical analysis}

The gastric disappearance of the individual proteins was calculated as follows:

$$
\begin{aligned}
& \text { True protein disappearance }(\%) \\
&=\left(\mathrm{BI}_{\text {diet }}-\left(\mathrm{BI}_{\text {chyme }} \times \mathrm{TiO}_{2 \text { diet }} / \mathrm{TiO}_{2 \text { chyme }}\right.\right. \\
&\left.\left.-\mathrm{BI}_{\text {endogenous protein flow }}\right)\right) / \mathrm{BI}_{\text {diet }} \times 100,
\end{aligned}
$$

where $\mathrm{BI}$ is the band intensity of each individual beef muscle protein measured as $\mathrm{ADU} / \mathrm{kg} \mathrm{DM}$ on the SDS-PAGE gels. $\mathrm{TiO}_{2}$ content was expressed as g/kg DM. 
The BI flows of endogenous proteins in the stomach were calculated using the following equation (expressed as $\mathrm{ADU} / \mathrm{kg} \mathrm{DM})$

$$
\begin{aligned}
& \mathrm{BI}_{\text {endogenous protein flow }}(\mathrm{ADU} / \mathrm{kg} \mathrm{DM} \text { intake }) \\
& \quad=\mathrm{BI}_{\text {chyme }}(\mathrm{ADU} / \mathrm{kg} \mathrm{DM}) \times \mathrm{TiO}_{2 \text { diet }} / \mathrm{TiO}_{2 \text { chyme }} .
\end{aligned}
$$

The time required to reach half of the gastric disappearance $\left(\mathrm{TD}_{50}\right)$ of each individual protein in each dietary treatment was calculated according to the Michaelis-Menten nonlinear model, with time replacing substrate concentration ${ }^{(22)}$ :

Gastric disappearance $(\%)=\alpha \times$ time $/(\beta+$ time $)$,

where the parameter $\alpha$ is the maximum gastric disappearance (100\%) at maximum time and $\beta$ the half time of gastric disappearance $\left(\mathrm{TD}_{50}\right)$. The parameter $\beta$ for the fitted curve of each diet and for each individual protein was estimated using the PROC NLIN of SAS (SAS Institute Inc.) $)^{(23)}$ via the GaussNewton method. The fitted curves of the diets were then compared using the $F$ test by considering whether the data for all the treatments were better explained by a single non-linear model (i.e. no difference between the treatments) or by individual non-linear models ${ }^{(24)}$. As the parameter $\beta$ was the only parameter differing between the fitted curves for each diet, the $P$ value obtained from the $F$ test described above was ascribed to the parameter $\beta$.

The true gastric degree of protein hydrolysis of the total beef muscle protein was calculated as follows:

$$
\begin{aligned}
& \text { True degree of protein hydrolysis }(\%) \\
& =\left(\mathrm{NH}_{2 \text { diet }}-\left(\left(\left(\mathrm{NH}_{2 \text { diet }}-\mathrm{NH}_{2 \text { chyme }}\right)-\mathrm{NH}_{2 \mathrm{EF}}\right)\right.\right. \\
& \left.\left.\times \mathrm{TiO}_{2 \text { diet }} / \mathrm{TiO}_{2 \text { chyme }}\right)\right) / \mathrm{NH}_{2 \text { diet }} \times 100 .
\end{aligned}
$$

where $\mathrm{NH}_{2}$ diet and $\mathrm{NH}_{2}$ chyme are the total amino groups in the diets and the amino groups in the chyme of each treatment, respectively, at each time point in $\mathrm{g} / \mathrm{kg} \mathrm{DM}$. $\mathrm{NH}_{2 \mathrm{EF}}$ is the flow of endogenous amino groups which was calculated from the stomach chyme of the pigs fed the protein-free diet (g/kg DM):

$$
\begin{aligned}
& \text { Endogenous } \mathrm{NH}_{2} \text { flow }(\mathrm{g} / \mathrm{kg} \mathrm{DM} \text { intake }) \\
& \quad=\mathrm{NH}_{2} \text { chyme }(\mathrm{g} / \mathrm{kgDM}) \times \mathrm{TiO}_{2} \text { diet } / \mathrm{TiO}_{2} \text { chyme } .
\end{aligned}
$$

The relative amounts of $\mathrm{DM}$ and $\mathrm{N}$ in the stomach over time (expressed as g DM) were determined as follows:

$$
\begin{aligned}
& \text { Relative } \mathrm{DM} \text { in the stomach over time }(\%) \\
& \quad=\mathrm{DM}_{(\text {time } i)} / \mathrm{DM}_{\text {(intake) }} \times 100,
\end{aligned}
$$

Relative $\mathrm{N}$ in the stomach over time (\%)

$$
\begin{aligned}
& =\left(\mathrm{DM} \times \text { concentration } \mathrm{N}_{(\text {time } i)}\right) / \\
& \left(\mathrm{DM} \times \text { concentration } \mathrm{N}_{(\text {intake })}\right) \times 100,
\end{aligned}
$$

where time $i(0 \cdot 5,1,3,5$ and $7 \mathrm{~h})$ is the time between when the pigs received their meal and when they were euthanised.

The relative retention of $\mathrm{DM}$ and $\mathrm{N}$ in the stomach was then analysed according to the power exponential model reported $^{(25)}$ :

Relative remaining time $=\alpha_{0} \exp -(\kappa \times \text { time })^{\beta}$, where $\alpha_{0}$ is the proportion remaining at time $0(100 \%)$. The parameters $\kappa$ (the slope of the curve) and $\beta$ (an index for the shape of the curve) for the fitted curves of each diet were estimated using the PROC NLIN of SAS ${ }^{(23)}$ via the Gauss-Newton method for each diet before being compared statistically $^{(24,26)}$. They were also used to determine the half gastric emptying time $\left(T_{1 / 2}\right)$ according to the equation proposed by Odunsi et al. ${ }^{(27)}$ :

$$
T_{1 / 2}=(1 / k) \times(\log (1 / 0 \cdot 5))^{(1 / \beta)} .
$$

To identify the time points where dietary actinidin influenced the response variables, an ANOVA was conducted, with the pig as the experimental unit, to test the effect of dietary treatment, time and their interaction (factorial design four dietary treatments $\times$ five time points) using the PROC MIXED procedure of $\mathrm{SAS}^{(23)}$. The model diagnostics of each variable based on its residuals were tested after combining the PROC UNIVARIATE and the ODS GRAPHICS procedures of SAS ${ }^{(23)}$ before comparing the means. A variable was transformed when it failed in one or more of the diagnostic model assumptions (expected mean of the residuals is 0 , independent residuals, constant variance across the treatments and normal distribution of the residuals). A completely randomised factorial design without replication ${ }^{(28)}$ was used to test the effect of the diet and the protein on the time required to reach half of the protein degradation using the PROC ANOVA procedure ${ }^{(23)}$.

\section{Results}

Apart from two pigs presenting loose stools during the first week of the trial, all of the pigs were healthy during the experiment. Data were gathered from all the pigs, and no data were excluded from the data analysis.

\section{Determined actinidin activity in the diets and the stomach chyme}

To confirm the presence or absence of actinidin in the diets and also to assess the stability of actinidin in the stomach, diet samples and stomach chyme samples from each pig were collected and actinidin activity determined (Table 2). As expected, the green kiwifruit test and gold kiwifruit positive control diets had higher actinidin activity than both the negative control diets $(P<0 \cdot 01)$.

In the stomach, there was an interaction between dietary treatment and time for actinidin activity in the chyme $(P<0.001)$. The actinidin activity was similar between the green kiwifruit negative control and gold kiwifruit negative control diets at all postprandial time points, but lower than the diets containing dietary actinidin during the first $5 \mathrm{~h}$ $(P<0.05)$. Additionally, the gold kiwifruit positive control diet had higher actinidin activity than the green kiwifruit test diet during the first $5 \mathrm{~h}$ of gastric digestion $(P<0.05)$, but at $7 \mathrm{~h}$, there was no difference in their actinidin activity. The average actinidin activity of the chyme for the pigs fed the protein free-diet was $27 \cdot 3 \mu \mathrm{mol}$-o-nitrophenol/min per $\mathrm{g} \mathrm{DM}$ (data not shown). There was a marked increase in actinidin activity between the dietary and chyme values for each diet. 
Table 2. Actinidin activity ( $\mu \mathrm{mol}-o$-nitrophenol/min per $\mathrm{g} \mathrm{DM}$ ) in the experimental diets and the stomach chyme of growing pigs fed the diets* (Mean values with their pooled standard errors, $n 30$ for diet, $n 6$ per chyme)

\begin{tabular}{|c|c|c|c|c|c|c|c|c|}
\hline & \multicolumn{2}{|c|}{ Green kiwifruit } & \multicolumn{2}{|c|}{ Gold kiwifruit } & \multirow[b]{2}{*}{ SEM } & \multicolumn{3}{|c|}{$P$} \\
\hline & Test & Negative control & Positive control & Negative control & & Diet & Time & Diet $\times$ time \\
\hline Diet & $35 \cdot 8^{a}$ & $4 \cdot 5^{\mathrm{b}}$ & $41 \cdot 3^{a}$ & $3 \cdot 3^{b}$ & $1 \cdot 32$ & $<0.001$ & - & - \\
\hline Chyme & - & - & - & - & $12 \cdot 81$ & $<0.001$ & $<0.001$ & $<0.001$ \\
\hline $0.5 \mathrm{~h}$ & $105 \cdot 2^{b, z}$ & $17 \cdot 0^{c, y}$ & $132 \cdot 4^{a, y}$ & $12 \cdot 2^{\mathrm{c}, \mathrm{y}}$ & & & & \\
\hline $1 \mathrm{~h}$ & $98 \cdot 7^{\mathrm{b}, \mathrm{z}}$ & $23 \cdot 8^{c, z, y}$ & $157 \cdot 0^{\mathrm{a}, \mathrm{y}}$ & $27 \cdot 3^{c, z, y}$ & & & & \\
\hline $3 h$ & $102 \cdot 5^{\mathrm{b}, \mathrm{z}}$ & $41 \cdot 7^{\mathrm{c}, \mathrm{z}}$ & $236 \cdot 9^{a, z}$ & $29 \cdot 5^{c, z}$ & & & & \\
\hline $5 \mathrm{~h}$ & $68 \cdot 9^{\mathrm{b}, \mathrm{z}}$ & $34 \cdot 2^{c, z, y}$ & $149 \cdot 0^{a, y}$ & $33 \cdot 6^{\mathrm{c}, \mathrm{z}}$ & & & & \\
\hline $7 \mathrm{~h}$ & $43 \cdot 5^{y}$ & $29 \cdot 6^{z, y}$ & $28 \cdot 1^{x}$ & $24 \cdot 7^{z, y}$ & & & & \\
\hline
\end{tabular}

${ }_{a, b, c}$ Mean values within a row with unlike superscript letters were significantly different $(P<0.05)$.

$z, y, x$ Mean values within a column with unlike superscript letters were significantly different $(P<0.05)$.

* The experimental diets contained beef muscle protein as the sole protein source containing either fresh green kiwifruit pulp (green kiwifruit test), green kiwifruit pulp with inactivated actinidin (green kiwifruit negative control), fresh gold kiwifruit pulp (gold kiwifruit negative control) or fresh gold kiwifruit pulp supplemented with purified actinidin to provide the same actinidin activity as in the green kiwifruit test diet (gold kiwifruit positive control).

\section{Effect of dietary actinidin on stomach emptying rate}

Recognising that the data are from a time-response study, and also considering the importance of identifying the time points at which dietary actinidin influenced both the stomach emptying and the gastric disappearance of beef muscle proteins, the results of the study were analysed using two approaches (time-response using established models and the multiple range test at each time point when the interaction between dietary treatment and time was statistically significant). Both approaches led to the same overall conclusions, but each approach provided additional insight.

The gastric DM content decreased during the postprandial period, such that between 80 and $93 \%$ of the consumed DM had exited the stomach at $7 \mathrm{~h}$ after the meal (Table 3). There was an interaction between dietary treatment and time on the amount of DM retained in the stomach $(P<0 \cdot 05)$. In general, the DM retained in the stomach was lower for the diets containing actinidin (green kiwifruit test and gold kiwifruit positive control) than for both the negative control diets at $1-3 \mathrm{~h}$ postprandially. The gold kiwifruit negative control diet was associated with a lower gastric DM content at $7 \mathrm{~h}$ compared with the green kiwifruit negative control and gold kiwifruit positive control diets $(P<0.05)$. The effect of dietary actinidin on DM retention was confirmed when the $\beta$ (shape of the curve) and $\kappa$ (slope of the curve) parameters were compared. The gold kiwifruit negative control diet had the highest $\beta$ parameter compared with the diets containing actinidin, while the green kiwifruit negative control diet had the lowest $\kappa$ parameter compared with the other diets $(P<0 \cdot 05)$. The values of the $\beta$ and $\kappa$ parameters were then used to estimate the time required to

Table 3. Gastric relative retention and gastric retention parameters of DM and nitrogen in growing pigs fed the experimental diets*

(Mean values with their pooled standard errors, $n 6$ )

\begin{tabular}{|c|c|c|c|c|c|c|c|c|}
\hline & \multicolumn{2}{|c|}{ Green kiwifruit } & \multicolumn{2}{|c|}{ Gold kiwifruit } & \multirow[b]{2}{*}{ SEM } & \multicolumn{3}{|c|}{$P$} \\
\hline & Test & Negative control & Positive control & Negative control & & Diet & Time & Diet $\times$ time \\
\hline \multicolumn{9}{|l|}{ DM } \\
\hline Retention (\%) & - & - & - & - & $2 \cdot 34$ & 0.001 & $<0.001$ & 0.019 \\
\hline $0.5 \mathrm{~h}$ & $83 \cdot 3^{z}$ & $87 \cdot 0^{z}$ & $81 \cdot 7^{z}$ & $87 \cdot 3^{z}$ & & & & \\
\hline $1 \mathrm{~h}$ & $70 \cdot 2^{b, y}$ & $78 \cdot 7^{a, y}$ & $69 \cdot 7^{\mathrm{b}, \mathrm{y}}$ & $78 \cdot 4^{a, y}$ & & & & \\
\hline $3 \mathrm{~h}$ & $40 \cdot 9^{b, x}$ & $52 \cdot 9^{a, x}$ & $46 \cdot 4^{\mathrm{a}, \mathrm{b}, \mathrm{x}}$ & $49 \cdot 8^{a, x}$ & & & & \\
\hline $5 \mathrm{~h}$ & $26 \cdot 8^{\mathrm{w}}$ & $28 \cdot 7^{\mathrm{w}}$ & $26 \cdot 1^{\mathrm{w}}$ & $23 \cdot 8^{\mathrm{w}}$ & & & & \\
\hline $7 \mathrm{~h}$ & $11 \cdot 8^{\mathrm{b}, \mathrm{v}}$ & $19 \cdot 9^{a, v}$ & $13 \cdot 3^{\mathrm{a}, \mathrm{v}}$ & $7 \cdot 2^{\mathrm{b}, \mathrm{v}}$ & & & & \\
\hline$\beta$ & $0.88^{\mathrm{b}}$ & $0.97^{\mathrm{a}, \mathrm{b}}$ & $0.86^{b}$ & $1 \cdot 17^{a}$ & 0.063 & 0.023 & - & - \\
\hline$\kappa$ & $0.30^{\mathrm{a}}$ & $0.22^{b}$ & $0.28^{a}$ & $0.27^{a}$ & 0.012 & 0.006 & - & - \\
\hline$T_{1 / 2} \dagger(\min )$ & $134^{c}$ & $184^{a}$ & $139^{b, c}$ & $159^{\mathrm{b}}$ & $7 \cdot 4$ & 0.004 & - & - \\
\hline \multicolumn{9}{|l|}{$\mathrm{N}$} \\
\hline Retention (\%) & $43 \cdot 7^{\mathrm{b}}$ & $49 \cdot 4^{\mathrm{a}}$ & $47 \cdot 4^{\mathrm{a}}$ & $47 \cdot 5^{\mathrm{a}}$ & $2 \cdot 31$ & 0.001 & $<0.001 \ddagger$ & 0.177 \\
\hline$\beta$ & $0.98^{\mathrm{b}}$ & $1 \cdot 10^{b}$ & $1.08^{b}$ & $1 \cdot 27^{\mathrm{a}}$ & 0.067 & 0.028 & - & - \\
\hline$\kappa$ & $0.34^{a}$ & $0.27^{b}$ & $0.29^{b}$ & $0.29^{b}$ & 0.012 & 0.011 & - & - \\
\hline$T_{1 / 2} \dagger(\min )$ & $123^{b}$ & $158^{\mathrm{a}}$ & $147^{a}$ & $152^{\mathrm{a}}$ & $6 \cdot 3$ & 0.008 & - & - \\
\hline
\end{tabular}

a,b,c Mean values within a row with unlike superscript letters were significantly different $(P<0.05)$.

$z, y, x$ Mean values within a column with unlike superscript letters were significantly different $(P<0 \cdot 05)$.

* The experimental diets contained beef muscle protein as a sole protein source containing either fresh green kiwifruit pulp (green kiwifruit test), green kiwifruit pulp with inactivated actinidin (green kiwifruit negative control), fresh gold kiwifruit pulp (gold kiwifruit negative control) or fresh gold kiwifruit pulp supplemented with purified actinidin to provide the same actinidin activity as in the green kiwifruit test diet (gold kiwifruit positive control).

$\dagger T_{1 / 2}$, the time at which half the DM or $\mathrm{N}$ had emptied from the stomach; this value was calculated based on the fitting parameters $(\beta$ and $\kappa)$ of a non-linear model ${ }^{(25)}$ and the equation ${ }^{(27)}$ described in the Experimental methods section.

$\ddagger$ The percentage of $\mathrm{N}$ retained in the stomach at $0 \cdot 5,1,3,5$ and $7 \mathrm{~h}$ was $86 \cdot 2^{\mathrm{a}}, 75 \cdot 3^{\mathrm{b}}, 45 \cdot 1^{\mathrm{c}}, 22 \cdot 4^{\mathrm{d}}$ and $6 \cdot 1^{\mathrm{e}}$, respectively. Values with unlike superscript letters were significantly different $(P<0.05)$. 
empty half of the gastric contents $\left(T_{1 / 2}\right) . T_{1 / 2}$ was $1 \cdot 3$-fold higher in the absence of dietary actinidin (159-184 min) than in its presence $(134-139 \mathrm{~min})(P<0 \cdot 01$; Table 3$)$.

The relative retention of $\mathrm{N}$ in the stomach was influenced by actinidin and time $(P<0 \cdot 01)$, but there was no interaction $(P>0.05)$ between actinidin and time. The $\mathrm{N}$ retained in the stomach was lower for the green kiwifruit test diet when compared with the other dietary treatments $(P<0.05)$. As expected, the amount of $\mathrm{N}$ retained in the stomach decreased over time $(P<0 \cdot 01)$. The gold kiwifruit negative control diet had the highest $\beta$ parameter compared with the other diets, while the green kiwifruit test diet had the highest $\kappa$ parameter compared with the other diets $(P<0.05)$. Based on previous results, the estimation of $T_{1 / 2}$ showed that the green kiwifruit test diet had a lower $T_{1 / 2}$ when compared with the other dietary treatments (123v. 147-158 min, $P<0 \cdot 01)$.

\section{Effect of dietary actinidin on the gastric hydrolysis of beef muscle proteins}

The effect of dietary actinidin on the gastric hydrolysis of the total beef muscle protein is shown in Table 4. For true gastric hydrolysis, there was an interaction between dietary treatment and time $(P<0 \cdot 001)$. The diets containing actinidin had higher gastric hydrolysis during the first $5 \mathrm{~h}$ postprandially than the diets without actinidin $(P<0 \cdot 001)$. In addition, the gold kiwifruit positive control diet had higher gastric hydrolysis at 3 and $5 \mathrm{~h}$ compared with the green kiwifruit test diet $(P<0.001)$. At $7 \mathrm{~h}$, there were no differences in gastric hydrolysis between the dietary treatments $(P>0 \cdot 05)$.

The proteins detected in the beef muscle preparation were similar to those seen previously ${ }^{(3)}$, including myosin heavy chain (MHC), $\beta$-actinin, $\alpha$-actinin, desmin, actin, tropomyosin- $\beta$-chain, tropomyosin- $\alpha$-chain, myosin light chain (MLC) 1, troponin I and MLC2, as well as unidentified proteins with molecular weights (MW) of 64, 45, 32, 29 and $25 \mathrm{kDa}$. In addition, two other unidentified proteins ( 88 and $43 \mathrm{kDa}$ ) were observed. The results from the SDS-PAGE analysis of the diet and chyme are given in Fig. 1, and the mean values for determined true gastric disappearance (\%) of each protein selected using the SDS-PAGE analysis are presented in Table 5 and Supplementary table (available online).
The overall true gastric disappearance of beef muscle proteins in the presence or absence of dietary actinidin ranged from 0 to $68 \%$ at $0.5 \mathrm{~h}, 0$ to $81 \%$ at $1 \mathrm{~h}, 15$ to $92 \%$ at $3 \mathrm{~h}, 38$ to $94 \%$ at $5 \mathrm{~h}$ and 61 to $100 \%$ at $7 \mathrm{~h}$ of digestion (Table 5 and Supplementary table (available online)). There was an interaction between dietary actinidin and time on the gastric disappearance of all the beef muscle proteins $(P<0.05)$, with the exception of the proteins $45 \mathrm{kDa}$, MLC 1, troponin $I$ and MLC2. In general, the true gastric disappearances of the beef muscle proteins of the green kiwifruit test and gold kiwifruit positive control diets were similar for most of the proteins across the different postprandial sampling times $(P>0.05)$. The only exceptions were tropomyosin- $\beta$-chain and tropomyosin- $\alpha$-chain at $1 \mathrm{~h}$ and tropomyosin- $\beta$-chain at $0.5 \mathrm{~h}$ postprandially, for which gastric disappearances were higher for the gold kiwifruit positive control diet $(P<0.05)$. Furthermore, the two negative control diets had similar degradability values for most of the proteins $(P>0.05)$, with the exceptions of MHC, $\beta$-actinin, $88 \mathrm{kDa}$, actin and tropomyosin- $\beta$-chain, for which the green kiwifruit negative control diet had higher true gastric disappearance values $(P<0.05)$ for some of the sampling times. Dietary actinidin increased the true gastric disappearance of several beef muscle proteins $(P<0.05)$ particularly for some of the higher-MW proteins (MHC, $\beta$-actinin, $\alpha$-actinin, $88 \mathrm{kDa}$, desmin, $45 \mathrm{kDa}, 43 \mathrm{kDa}$, actin, tropomyosin- $\beta$-chain and tropomyosin- $\alpha$-chain). For these proteins, the true gastric disappearances were higher for the diets containing actinidin (green kiwifruit test and gold kiwifruit positive control) compared with the two negative control diets, especially during the first $3 \mathrm{~h}$ of digestion $(P<0 \cdot 05)$. However, from $5 \mathrm{~h}$ onwards, there were no differences among the dietary treatments $(P>0.05)$. In contrast, the true gastric disappearance of proteins with low MW (MLC1, troponin I and MLC2) was only influenced by time $(P<0.05)$.

The time required to reach half of the gastric disappearance (TD $_{50}$ or the parameter $\beta$ in the non-linear gastric disappearance model) for each individual protein in each dietary treatment reflects the results above (Table 5). In general for both the negative control diets, a longer time was required to reach half of the protein disappearance than was required for the green kiwifruit test and gold kiwifruit positive control

Table 4. True gastric hydrolysis of dietary proteins in growing pigs fed the experimental diets*

(Mean values with their pooled standard errors, $n 6$ )

\begin{tabular}{|c|c|c|c|c|c|c|c|c|}
\hline & \multicolumn{2}{|c|}{ Green kiwifruit } & \multicolumn{2}{|c|}{ Gold kiwifruit } & \multirow[b]{2}{*}{ SEM } & \multicolumn{3}{|c|}{$P$} \\
\hline & Test & Negative control & Positive control & Negative control & & Diet & Time & Diet $\times$ time \\
\hline Gastric hydrolysis (\%) & - & - & - & - & 1.51 & $<0.001$ & $<0.001$ & $<0.001$ \\
\hline $0.5 \mathrm{~h}$ & $15 \cdot 5^{\mathrm{a}, \mathrm{y}}$ & $11 \cdot 2^{\mathrm{b}, \mathrm{z}}$ & $15 \cdot 4^{a, x}$ & $8 \cdot 3^{c, y, x}$ & & & & \\
\hline $1 \mathrm{~h}$ & $16 \cdot 8^{a, z, y}$ & $10 \cdot 7^{\mathrm{b}, \mathrm{z}}$ & $20 \cdot 1^{a, y}$ & $8 \cdot 6^{\mathrm{b}, \mathrm{y}}$ & & & & \\
\hline $3 \mathrm{~h}$ & $20 \cdot 9^{b, z}$ & $13 \cdot 0^{c, z}$ & $27 \cdot 0^{a, z}$ & $14 \cdot 0^{c, z}$ & & & & \\
\hline $5 \mathrm{~h}$ & $16 \cdot 8^{b, z, y}$ & $11 \cdot 5^{\mathrm{c}, \mathrm{z}}$ & $22 \cdot 3^{a, y}$ & $11 \cdot 3^{\mathrm{c}, \mathrm{z}, \mathrm{y}}$ & & & & \\
\hline $7 \mathrm{~h}$ & $6 \cdot 0^{\mathrm{x}}$ & $4 \cdot 3^{y}$ & $4 \cdot 2^{w}$ & $4 \cdot 8^{\mathrm{x}}$ & & & & \\
\hline
\end{tabular}

a,b,c Mean values within a row with unlike superscript letters were significantly different $(P<0.05)$

$z, y, x$ Mean values within a column with unlike superscript letters were significantly different $(P<0.05)$

* The experimental diets contained beef muscle protein as a sole protein source containing either fresh green kiwifruit pulp (green kiwifruit test), green kiwifruit pulp with inactivated actinidin (green kiwifruit negative control), fresh gold kiwifruit pulp (gold kiwifruit negative control) or fresh gold kiwifruit pulp supplemented with purified actinidin to provide the same actinidin activity as in the green kiwifruit test diet (gold kiwifruit positive control). 
(a)

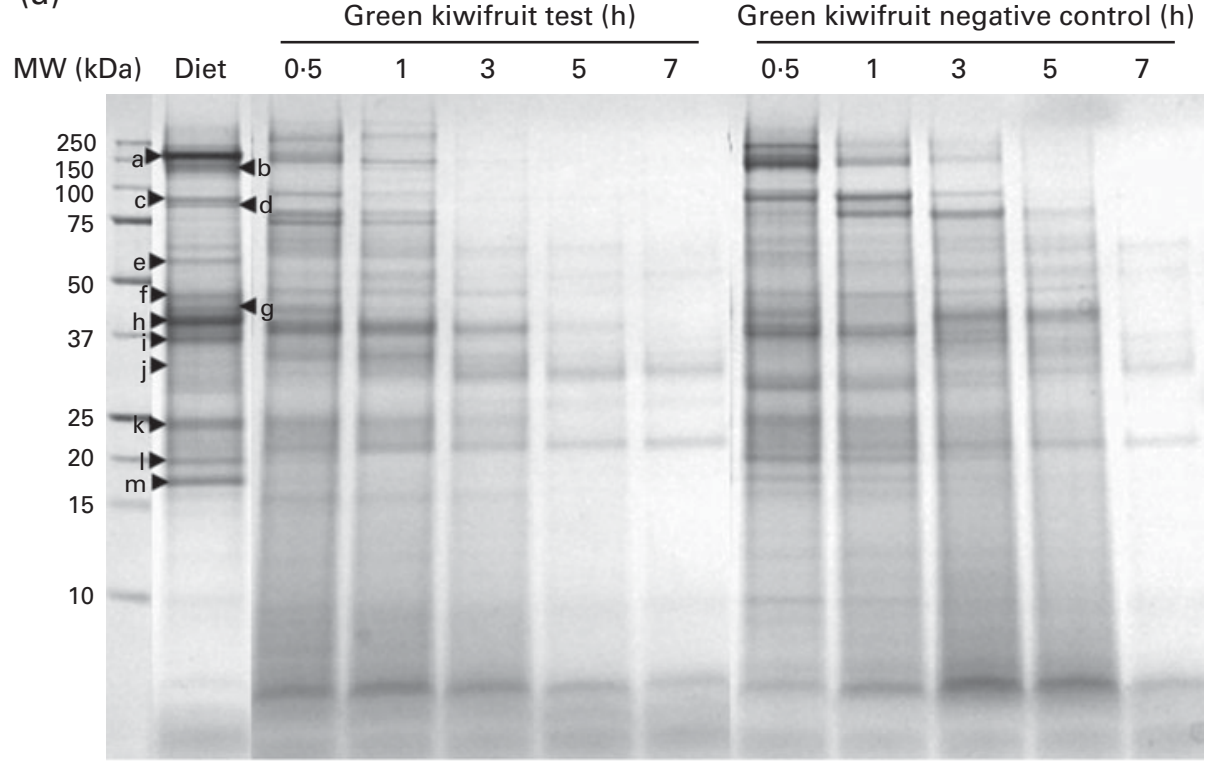

(b)

Gold kiwifruit positive control (h) Gold kiwifruit negative control (h)

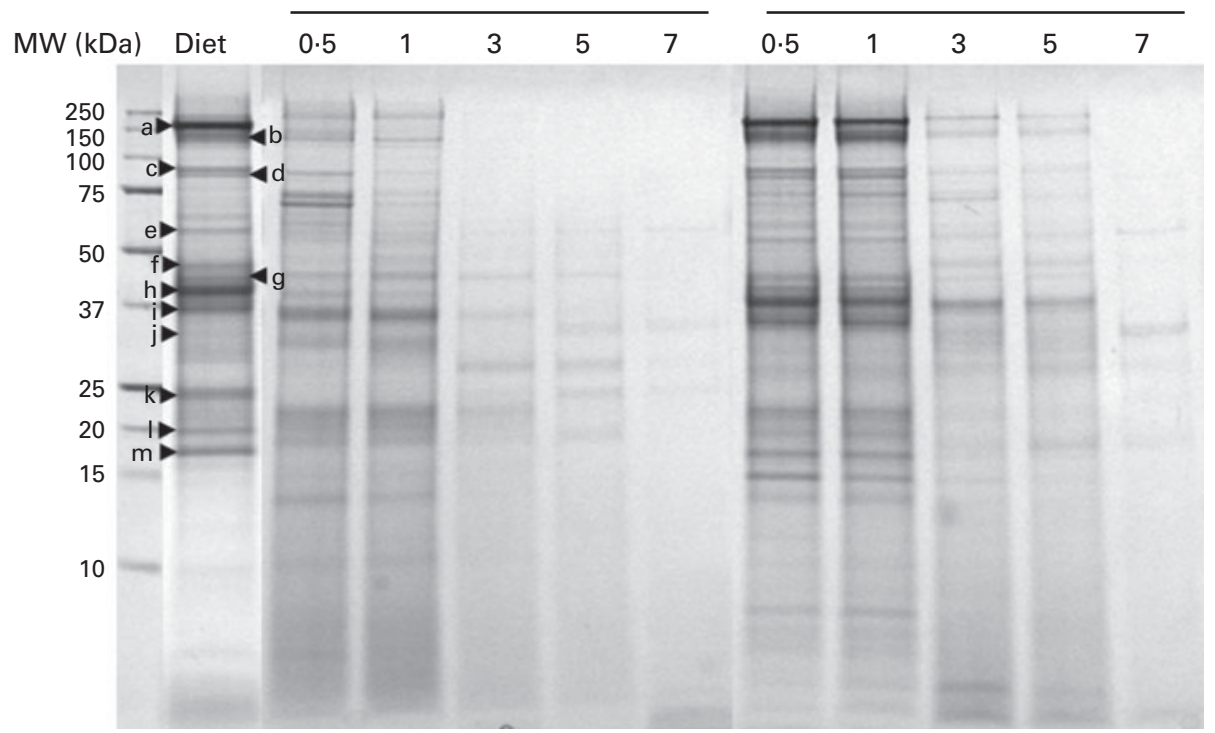

Fig. 1. SDS-PAGE analysis of a beef muscle protein diet and stomach chyme of growing pigs sampled at $0.5,1,3,5$ and $7 \mathrm{~h}$ after consuming the diets: (a) green kiwifruit test and green kiwifruit negative control or (b) gold kiwifruit positive control and gold kiwifruit negative control. The amount of the sample loaded in each lane was normalised based on the DM per $\mathrm{ml}$ of Tricine sample buffer $(10 \mathrm{mg} / \mathrm{ml})$. The protein bands were identified as follows: a, myosin heavy chain; b, $\beta$-actinin; c, $\alpha$-actinin; d, $88 \mathrm{kDa}$ protein; e, desmin; f, $45 \mathrm{kDa}$ protein; g, $43 \mathrm{kDa}$; h, actin; i, tropomyosin- $\beta$-chain; j, tropomyosin- $\alpha$-chain; k, myosin light chain 1 ; I, troponin I; m, myosin light chain 2. MW, molecular weight.

diets (e.g. the $\mathrm{TD}_{50}$ for $\mathrm{MHC}$ was $>36$ and $<22 \mathrm{~min}$ for the diets without and with dietary actinidin, respectively; $P<0 \cdot 01$; Fig. 2).

Also, there was a difference among the proteins (within the diet) for the time required for half of the amount of each protein present to disappear $\left(\mathrm{TD}_{50}\right)(P<0 \cdot 001)$. MHC, $\beta$-actinin, $\alpha$-actinin, actin, MLC2, and the unidentified 88,45 and $43 \mathrm{kDa}$ proteins required less time to reach $50 \%$ disappearance $\left(\mathrm{TD}_{50}=22-76 \mathrm{~min}\right.$ for the green kiwifruit test diet) than the remaining proteins (e.g. 119-357 $\mathrm{min}$ for the green kiwifruit test diet).

\section{Discussion}

Actinidin is a cysteine protease present in several varieties of kiwifruit. Actinidin has been shown to increase the rate and extent of both gastric and intestinal digestion of different dietary proteins, including beef muscle, in both in vitro ${ }^{(2)}$ and in vivo ${ }^{(3)}$ studies with rats. Beef muscle protein was chosen here to explore the effect of dietary actinidin on other factors such as the SER and the kinetics of gastric hydrolysis of proteins in the growing pig during a $7 \mathrm{~h}$ postprandial period. The pig was chosen as an animal model for humans, given 
Table 5. True gastric disappearance and time to reach half of the gastric true disappearance $\left(\mathrm{TD}_{50}\right)$ of proteins in growing pigs fed the experimental diets

(Mean values with their pooled standard errors, $n 6$ )

\begin{tabular}{|c|c|c|c|c|c|c|c|c|}
\hline \multirow[b]{2}{*}{ Protein* (band ID) } & \multicolumn{2}{|c|}{ Green kiwifruit } & \multicolumn{2}{|c|}{ Gold kiwifruit } & \multirow[b]{2}{*}{ SEM } & \multicolumn{3}{|c|}{$P$} \\
\hline & Test & Negative control & Positive control & Negative control & & Diet & Time & Diet $\times$ time \\
\hline \multicolumn{9}{|c|}{ Gastric disappearance (\%)† } \\
\hline $\mathrm{MHC}(\mathrm{a})$ & - & - & - & - & 4.29 & $<0.001$ & $<0.001$ & $<0.001$ \\
\hline $0.5 \mathrm{~h}$ & $64 \cdot 3^{a, x}$ & $51 \cdot 8^{\mathrm{b}, \mathrm{w}}$ & $68 \cdot 4^{a, x}$ & $29 \cdot 4^{\mathrm{c}, \mathrm{w}}$ & & & & \\
\hline $1 \mathrm{~h}$ & $76 \cdot 7^{\mathrm{a}, \mathrm{y}}$ & $63 \cdot 9^{\mathrm{b}, \mathrm{x}}$ & $81 \cdot 3^{\mathrm{a}, \mathrm{y}}$ & $25 \cdot 8^{\mathrm{c}, \mathrm{w}}$ & & & & \\
\hline $3 \mathrm{~h}$ & $92 \cdot 1^{\mathrm{a}, \mathrm{z}}$ & $83 \cdot 9^{b, y}$ & $90 \cdot 3^{\mathrm{a}, \mathrm{b}, \mathrm{z}}$ & $61 \cdot 6^{\mathrm{c}, \mathrm{x}}$ & & & & \\
\hline $5 \mathrm{~h}$ & $94 \cdot 0^{\mathrm{a}, \mathrm{z}}$ & $93 \cdot 6^{a, z}$ & $93 \cdot 2^{\mathrm{a}, \mathrm{z}}$ & $84 \cdot 2^{b, y}$ & & & & \\
\hline $7 \mathrm{~h}$ & $96 \cdot 1^{z}$ & $97 \cdot 9^{z}$ & $93 \cdot 8^{z}$ & $96 \cdot 1^{z}$ & & & & \\
\hline Actin (h) & - & - & - & - & 4.37 & $<0.001$ & $<0.001$ & 0.003 \\
\hline $0.5 \mathrm{~h}$ & $44 \cdot 9^{\mathrm{a}, \mathrm{w}}$ & $45 \cdot 9^{\mathrm{a}, \mathrm{w}}$ & $55 \cdot 4^{\mathrm{a}, \mathrm{x}}$ & $28 \cdot 7^{\mathrm{b}, \mathrm{w}}$ & & & & \\
\hline $1 \mathrm{~h}$ & $61 \cdot 5^{\mathrm{a}, \mathrm{x}}$ & $49 \cdot 1^{\mathrm{b}, \mathrm{x}, \mathrm{w}}$ & $65 \cdot 4^{\mathrm{a}, \mathrm{x}}$ & $26 \cdot 1^{\mathrm{c}, \mathrm{w}}$ & & & & \\
\hline $3 \mathrm{~h}$ & $81 \cdot 3^{\mathrm{a}, \mathrm{y}}$ & $57 \cdot 9^{\mathrm{b}, \mathrm{x}}$ & $81 \cdot 6^{\mathrm{a}, \mathrm{y}}$ & $50 \cdot 6^{\mathrm{b}, \mathrm{x}}$ & & & & \\
\hline $5 \mathrm{~h}$ & $89 \cdot 1^{a, z, y}$ & $77 \cdot 4^{\mathrm{a}, \mathrm{b}, \mathrm{y}}$ & $88 \cdot 7^{a, z, y}$ & $73 \cdot 1^{b, y}$ & & & & \\
\hline $7 \mathrm{~h}$ & $94 \cdot 5^{z}$ & $95 \cdot 3^{z}$ & $94 \cdot 4^{z}$ & $93 \cdot 4^{z}$ & & & & \\
\hline MLC1 (k) & $50 \cdot 6$ & 44.9 & 41.5 & $45 \cdot 4$ & 6.57 & 0.188 & $<0.001 \ddagger$ & 0.719 \\
\hline \multicolumn{9}{|l|}{$\mathrm{TD}_{50}(\mathrm{~min}) \S$} \\
\hline $\mathrm{MHC}(\mathrm{a})$ & $21 \cdot 8^{\mathrm{c}}$ & $36 \cdot 2^{b}$ & $15 \cdot 1^{\mathrm{c}}$ & $111.6^{\mathrm{a}}$ & $6 \cdot 72$ & $<0.001$ & - & - \\
\hline$\beta$-Actinin (b) & $42 \cdot 5^{\mathrm{c}}$ & $72 \cdot 2^{\mathrm{b}}$ & $27 \cdot 5^{\mathrm{C}}$ & $172 \cdot 2^{\mathrm{a}}$ & $12 \cdot 00$ & $<0.001$ & - & - \\
\hline$\alpha$-Actinin (c) & $35 \cdot 8^{\mathrm{C}}$ & $66 \cdot 9^{\mathrm{b}}$ & $26 \cdot 4^{c}$ & $128 \cdot 2^{\mathrm{a}}$ & $9 \cdot 36$ & $<0.001$ & - & - \\
\hline 88 (d) & $47 \cdot 7^{\mathrm{b}}$ & $170 \cdot 7^{\mathrm{a}}$ & $42 \cdot 7^{\mathrm{b}}$ & $178 \cdot 6^{\mathrm{a}}$ & 22.5 & $<0.001$ & - & - \\
\hline Desmin $(e)$ & $119 \cdot 1$ & $127 \cdot 2$ & $93 \cdot 2$ & $137 \cdot 1$ & $14 \cdot 88$ & 0.485 & - & - \\
\hline $45(\mathrm{f})$ & $66 \cdot 6^{\mathrm{b}}$ & $95 \cdot 0^{\mathrm{a}, \mathrm{b}}$ & $65 \cdot 4^{\mathrm{b}}$ & $116 \cdot 3^{\mathrm{a}}$ & $9 \cdot 82$ & 0.002 & - & - \\
\hline $43(\mathrm{~g})$ & $45 \cdot 3^{b}$ & $86 \cdot 8^{\mathrm{a}}$ & $36 \cdot 7^{b}$ & $124 \cdot 8^{\mathrm{a}}$ & $9 \cdot 13$ & $<0.001$ & - & - \\
\hline Actin (h) & $37 \cdot 2^{\mathrm{c}}$ & $63.0^{\mathrm{b}}$ & $29 \cdot 0^{\mathrm{C}}$ & $124 \cdot 0^{\mathrm{a}}$ & $7 \cdot 84$ & $<0.001$ & - & - \\
\hline T- $\beta$-chain (i) & $128 \cdot 4^{\mathrm{a}}$ & $123 \cdot 3^{\mathrm{a}}$ & $75 \cdot 9^{b}$ & $177 \cdot 6^{a}$ & $14 \cdot 7$ & $<0.001$ & - & - \\
\hline $\mathrm{T}-\alpha$-chain (j) & 356.5 & $300 \cdot 8$ & $196 \cdot 4$ & $323 \cdot 8$ & $49 \cdot 7$ & 0.156 & - & - \\
\hline MLC1 (k) & $135 \cdot 3$ & $180 \cdot 5$ & 218.0 & $185 \cdot 0$ & 26.05 & 0.480 & - & - \\
\hline Troponin I (I) 162.7 & $216 \cdot 3$ & 138.5 & $223 \cdot 0$ & 28.92 & 0.264 & - & - & \\
\hline $\operatorname{MLC2}(\mathrm{m})$ & $75 \cdot 7$ & $119 \cdot 0$ & $86 \cdot 1$ & $105 \cdot 9$ & $12 \cdot 11$ & $0 \cdot 181$ & - & - \\
\hline
\end{tabular}

ID, identification; MHC, myosin heavy chain; MLC, myosin light chain; T- $\beta$-chain, tropomyosin- $\beta$-chain; T- $\alpha$-chain, tropomyosin- $\alpha$-chain.

a,b,c Mean values within a row with unlike superscript letters were significantly different $(P<0.05)$.

${ }^{z, y, x}$ Mean values within a column with unlike superscript letters were significantly different $(P<0.05)$.

* The experimental diets contained beef muscle protein as a sole protein source containing either fresh green kiwifruit pulp (green kiwifruit test), green kiwifruit pulp with inactivated actinidin (green kiwifruit negative control), fresh gold kiwifruit pulp (gold kiwifruit negative control) or fresh gold kiwifruit pulp supplemented with purified actinidin to provide the same actinidin activity as in the green kiwifruit test diet (gold kiwifruit positive control).

† MHC, actin and MLC1 were selected for this table because they are some of the main beef muscle proteins and they described the effect of actinidin on their gastric disappearance. The gastric disappearance for the other proteins is detailed in the Supplementary table (available online).

$\ddagger$ The gastric disappearance of MLC1 at $0.5,1,3,5$ and $7 \mathrm{~h}$ was $15 \cdot 3^{\mathrm{d}}, 15 \cdot 9^{\mathrm{d}}, 40 \cdot 6^{\mathrm{c}}, 67 \cdot 5^{\mathrm{b}}$ and $88 \cdot 7^{\mathrm{a}}$, respectively. Values with unlike superscript letters were significantly different $(P<0.05)$.

$\S$ This value was calculated based on the Michaelis-Menten model described in the Experimental methods section. The $P$ value reported for the TD $\mathrm{D}_{50}$ was obtained after comparing the fitted curve for the diets. The mean comparison between the treatments was conducted from the confidence limits at $95 \%$ reported after fitting the non-linear model.

the close similarities in the physiology of digestion between the two species ${ }^{(9,29)}$. Determination of the gastric hydrolysis or disappearance of proteins was based on the extracted soluble proteins, and insoluble proteins would not have been considered. The SDS-PAGE technique is a useful method for estimating the gastric disappearance of individual proteins within a complex protein mixture ${ }^{(3)}$; however, it is a semiquantitative method, and may overestimate the gastric disappearance of a protein as only a single bond break is required for the protein (original MW) to disappear from the gel and reappear as two new separate protein bands. However, in the SDS-PAGE gels of the beef muscle shown here, new bands were not observed. A protein-free diet was used to determine the endogenous proteins present in the gastric chyme and, as expected, few endogenous protein bands were present. Some of the observed endogenous proteins had MW similar to some of the beef muscle proteins $(57,46$ and $36 \mathrm{kDa}$ ). For the beef muscle proteins desmin, $45 \mathrm{kDa}$ and tropomyosin- $\beta$-chain, gastric disappearance was corrected accordingly. For the remaining beef muscle proteins, no correction was necessary. Titanium dioxide is frequently used in nutrition studies as a solid-phase marker for determining nutrient flows. In the present study, titanium dioxide represented both the solid and liquid phases. The latter is a caveat of the study as the liquid phase may have a faster SER than the solid phase. Nevertheless, we assumed that this potential difference was small and constant across the treatments.

In the present study, some 'actinidin activity' was detected in the chyme of pigs fed the protein-free diet and the negative control diets, where no actinidin was present. The determined activity found in these samples may be explained by a proteolytic effect of pepsin on the substrate Cbz-L-Lys-Onitrophenol hydrochloride, suggesting that the method is not specific to actinidin, and the determined values for actinidin activity should be viewed as approximations. Surprisingly, actinidin activity in the chyme was about double that found in the diets. Due to the low specificity of the method 


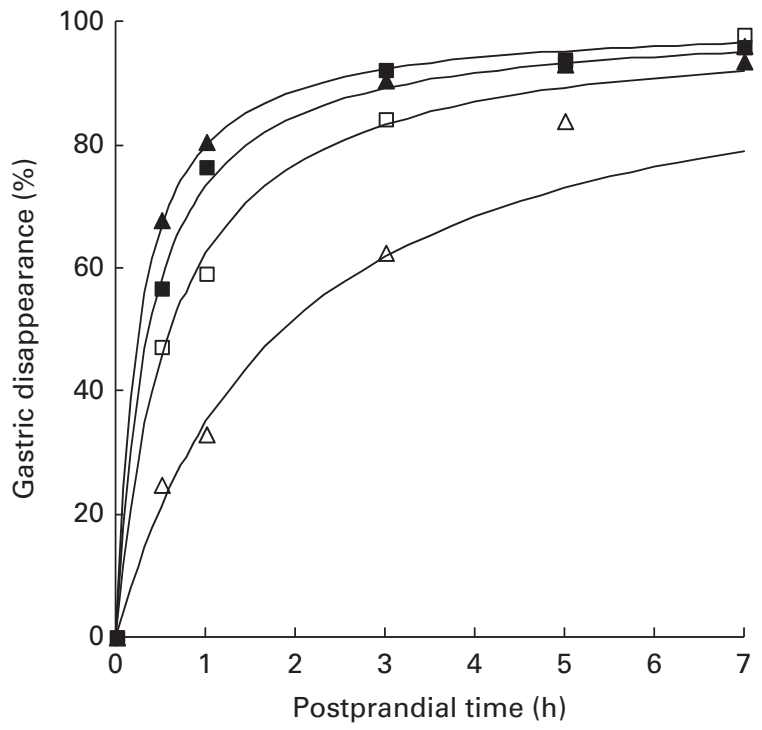

Fig. 2. Fitted curves ${ }^{(22)}$ of gastric disappearance for myosin heavy chain in growing pigs fed the green kiwifruit negative control $(\square)$, green kiwifruit test $(\square)$, gold kiwifruit negative control $(\Delta)$ and gold kiwifruit positive control $(\boldsymbol{\Lambda})$ diets. The pooled standard error of the fitted curves was $4.46 \%$.

to determine actinidin activity in the chyme, as described above, this increase could be explained by the activation of the pro-enzyme form of actinidin by either $\mathrm{HCl}$, actinidin itself or pepsin in the chyme. Significant amounts of cysteine proteases are known to be present as the pro-enzyme ${ }^{(30)}$. This increase in activity could also be explained by the conversion of pepsinogen to pepsin, which normally occurs in the stomach in the presence of $\mathrm{HCl}$ and pepsin ${ }^{(31)}$. Such conversion could be enhanced by the presence of cysteine proteases, which are known to activate pro-enzymes ${ }^{(30,32)}$

The reduction in actinidin activity at $7 \mathrm{~h}$ postprandially is most probably explained in that stomach emptying was largely complete by $7 \mathrm{~h}$ (only $10 \%$ of the DM remained in the stomach at this time), and therefore most of the actinidin would have exited the stomach. The lower level of actinidin activity in the chyme for the green kiwifruit test diet compared with the gold kiwifruit positive control diet may potentially be explained by actinidin being entrapped in the cell walls of green kiwifruit that differs from the gold kiwifruit positive control diet to which purified actinidin was added. Further experiments focusing on the gastric activation of actinidin may be warranted.

Gastric emptying is a complex process in which several factors including meal size ${ }^{(33)}$, diet composition ${ }^{(34,35)}$ and plasma hormone levels ${ }^{(6,7,36)}$ may play a role in its control. For example, the release of proteins and lipids into the duodenum modulates the secretion of the hormone cholecystokinin, which in turn reduces gastric motility and stomach emptying ${ }^{(6,7,37)}$. The presence of actinidin (in the form of fresh green kiwifruit pulp or purified actinidin added to the gold kiwifruit pulp) in the diets increased the rate of stomach emptying of DM and proteins during the first $3 \mathrm{~h}$ postprandially.

The effect of actinidin on accelerating stomach emptying has also been observed in rats fed with a beef muscle protein diet, and determined using a magnetic resonance spectroscopy approach ${ }^{(38)}$. During the $2.5 \mathrm{~h}$ period after feeding the rats, $41 \%$ of the stomach contents had emptied for a beef muscle protein diet containing green kiwifruit. However, a lesser amount (32\%) had emptied from the stomach for an equivalent beef muscle protein diet containing actinidin-devoid gold kiwifruit.

The presence of dietary actinidin in a beef muscle protein diet increased the rate of hydrolysis of the total beef muscle protein during the first $5 \mathrm{~h}$ postprandially (based on the degree of hydrolysis) and the rate of disappearance of the high-MW proteins (MHC, $\beta$-actinin, $\alpha$-actinin, desmin, actin, tropomyosin- $\beta$-chain and tropomyosin- $\alpha$-chain and unidentified proteins with MW of 88,45 and $43 \mathrm{kDa}$ ) for the first $3 \mathrm{~h}$. In contrast, there was much less effect of dietary actinidin on the lower-MW proteins $(<34 \mathrm{kDa})$. The extent of gastric disappearance varied markedly among the individual beef muscle proteins probably as a result of inter-protein differences at the structural level (e.g. different amino acid sequences and tertiary structure leading to different susceptibilities to proteases). After $5 \mathrm{~h}$ post-ingestion, actinidin did not further enhance gastric disappearance for most of the beef muscle proteins. It is likely that the hydrolytic action of pepsin and actinidin on the digestion of the beef muscle proteins was essentially complete (as judged by the method used in the present study) $5 \mathrm{~h}$ postprandially. The mean disappearance values across all the proteins and all the treatments after $5 \mathrm{~h}$ were between 75 and $83 \%$.

A high correlation between gastric protein digestion and gastric DM retention has been observed in rats fed different protein sources $(r 0.69)^{(38)}$. Thus, the present results may infer that the faster stomach emptying observed for the pigs fed with diets containing actinidin is mainly due to greater gastric digestion of the beef muscle proteins by actinidin rather than by a hormone-mediated change in gastric motility, as has been described previously for cholecystokinin ${ }^{(6,7,37)}$. The greater gastric hydrolysis and more rapid stomach emptying of the beef muscle proteins when pigs were fed a diet containing actinidin suggest a higher release of peptides and amino acids into the duodenum, which may result in a more rapid digestion and absorption in the small intestine with implications for the rates of amino acid delivery to the cells. The coordination of nutrient delivery (including amino acids) is an important, but often overlooked, factor for utilisation ${ }^{(4,8,39)}$. Moreover, it is possible that actinidin, consumed as part of whole kiwifruit, may be a means by which dietary amino acid delivery to the cells can be modulated. This hypothesis warrants investigation.

In conclusion, the presence of dietary actinidin in a beef muscle protein-based diet significantly enhanced the gastric disappearance of the higher-MW proteins $(>32 \mathrm{kDa})$ during the first $3 \mathrm{~h}$ postprandially, but had little effect on the smaller proteins $(<32 \mathrm{kDa})$. This enhancement in disappearance correlated with an increase in the SER of both DM and proteins during the same period. After $5 \mathrm{~h}$ postprandially, dietary actinidin had little further effect on the gastric hydrolysis of the beef muscle proteins and on stomach emptying. The implications of these findings are that actinidin assists the gastric digestion of meat protein and may potentially assist to reduce the feeling of stomach fullness experienced after 
consuming high-meat diets. The effect of dietary actinidin on the gastric hydrolysis of beef muscle proteins may also have an impact on the rate at which amino acids are absorbed from the gastrointestinal tract.

\section{Supplementary material}

To view supplementary material for this article, please visit http://dx.doi.org/10.1017/S0007114513003401

\section{Acknowledgements}

We acknowledge Stuart Saigeman for running the animal trial and ZESPRI International Limited for supplying the kiwifruit.

The present study was funded by ZESPRI International Limited. ZESPRI International Limited had no role in the design, analysis or writing of this article other than the contribution described in the authorship for L. N. D.

C. A. M., S. M. R., M. J. B. and P. J. M. were responsible for planning the study, which was accepted by L. N. D. before being conducted. C. A. M. and T. D. O. were responsible for conducting the experiment in pigs. A. S. P. was responsible for preparing and analysing the SDS-PAGE gels. Additionally, C. A. M. performed the statistical analysis and prepared the first draft of the manuscript that was revised by S. M. R., L. N. D., M. J. B. and P. J. M. All authors read and approved the final manuscript.

L. N. D. is employed by ZESPRI International Limited. There are no other conflicts of interest.

\section{References}

1. Boland M (2013) Kiwifruit proteins and enzymes: actinidin and other significant proteins. Adv Food Nutr Res 68, 59-80.

2. Kaur L, Rutherfurd SM, Moughan PJ, et al. (2010) Actinidin enhances gastric protein digestion as assessed using an in vitro gastric digestion model. J Agric Food Chem 58, 5068-5073.

3. Rutherfurd SM, Montoya CA, Zou ML, et al. (2011) Effect of actinidin from kiwifruit (Actinidia deliciosa cv. Hayward) on the digestion of food proteins determined in the growing rat. Food Chem 129, 1681-1689.

4. Rehner G, Heil M, Auge M, et al. (1985) Effect of proteins on availability of zinc. I. Gastrointestinal transit time of casein and whey protein and zinc absorption in weaned rats. $Z$ Ernährungswiss 24, 245-255.

5. Hara H, Nishikawa H \& Kiriyama S (1992) Different effects of casein and soyabean protein on gastric emptying of protein and small intestinal transit after spontaneous feeding of diets in rats. Br J Nutr 68, 59-66.

6. Mearadji B, Masclee AA, Onkenhout W, et al. (2001) Effect of intraduodenal and intravenous amino acids on proximal gastric motor function in man. Dig Dis Sci 46, 38-45.

7. Feinle C, Christen M, Grundy D, et al. (2002) Effects of duodenal fat, protein or mixed-nutrient infusions on epigastric sensations during sustained gastric distension in healthy humans. Neurogastroenterol Mot 14, 205-213.

8. Mahé S, Roos N, Benamouzig R, et al. (1996) Gastrojejunal kinetics and the digestion of [15N] $\beta$-lactoglobulin and casein in humans: the influence of the nature and quantity of the protein. Am J Clin Nutr 63, 546-552.
9. Moughan PJ \& Rowan AM (1989) The pig as a model animal for human nutrition research. Proc Nutr Soc 14, 116-123.

10. Baer DJ, Rumpler WV, Miles CW, et al. (1997) Dietary fibre decreases the metabolisable energy content and nutrient digestibility of mixed diets fed to humans. $J$ Nutr 127, 579-586.

11. Bublin M, Mari A, Ebner C, et al. (2004) IgE sensitisation profiles toward green and gold kiwifruits differ among patients allergic to kiwifruit from 3 European countries. J Allergy Clin Immunol 114, 1169-1175.

12. Henare SJ, Rutherfurd SM, Drummond L, et al. (2012) Digestible nutrients and available (ATP) energy contents of two varieties of kiwifruit (Actinidia deliciosa and Actinidia chinensis). Food Chem 130, 67-72.

13. Kniel KE, Sumner SS, Lindsay DS, et al. (2003) Effect of organic acids and hydrogen peroxide on Cryptosporidium parvum viability in fruit juices. J Food Protect 66, 1650-1657.

14. Food and Drug Administration (2003) Department of Health and Human Service. 21 CFR Part 356. Fed Reg 68, 32232-32287.

15. Material Safety Data Sheet (2011) Hydrogen peroxide $30 \%$. Science Lab.com. Chemicals and Laboratory Equipment. http://www.sciencelab.com/msds.php?msdsId=9924299 (accessed November 2011).

16. National Research Council (1998) Nutrient Requirements of Swine, 10th revised ed. Washington, DC: National Academy of Sciences-National Research Council.

17. Association of Official Analytical Chemists (2007) Official Methods of Analysis, 18th ed. Arlington, VA: AOAC.

18. Prosky L, Asp NG, Schweizer TF, et al. (1988) Determination of insoluble, soluble, and total dietary fibre in foods and food products: interlaboratory study. J Assoc Off Anal Chem Int 71, 1017-1023.

19. Short FJ, Gorton P, Wiseman J, et al. (1996) Determination of titanium dioxide added as an inert marker in chicken digestibility studies. Anim Feed Sci Technol 59, 215-221.

20. Boland MJ \& Hardman MJ (1972) Kinetic studies on the cysteine proteinase from Actinidia chinensis. FEBS Lett 27, 282-284.

21. Church F, Swaisgood H, Porter DH, et al. (1983) Spectrophotometric assay using $o$-phthaldialdehyde for determination of proteolysis in milk and isolated milk proteins. J Dairy Sci 66 , 1219-1227.

22. Lopez S, France J, Gerrits WJJ, et al. (2000) A generalized Michaelis-Menten equation for the analysis of growth. J Anim Sci 78, 1816-1828.

23. SAS (2009) User's Guide Statistics. Version 9.2. Statistical Analysis System. Cary, NC: SAS Institute, Inc.

24. Bruin J (2006) Newtest: Command to Compute New Test. UCLA: Academic Technology Services, Statistical Consulting Group. http://www.ats.ucla.edu/stat/stata/ado/ analysis/ (accessed May 2012).

25. Elashoff JD, Reedy TJ \& Meyer JH (1982) Analysis of gastric emptying data. Gastroenterology 83, 1306-1312.

26. Freund R \& Littell R (2000) SAS System for Regression, 3rd ed. Cary, NC: SAS Publishing.

27. Odunsi ST, Camilleri M, Szarka LA, et al. (2009) Optimizing analysis of stable isotope breath tests to estimate gastric emptying of solids. Neurogastroenterol Motil 21, 706-e38.

28. Milliken GA \& Johnson DE (1989) Analysis of Messy Data: Volume 2: Nonreplicated Experiments. New York, NY: Van Nostrand Reinhold.

29. Rowan AM, Moughan PJ, Wilson MN, et al. (1994) Comparison of the ileal and faecal digestibility of dietary amino acids in adult humans and evaluation of the pig as a model animal for digestion studies in man. BrJ Nutr 71, 29-42. 
30. Turk V, Podobnik M, Turk B, et al. (1997) Regulation of cysteine proteinase activity by protein inhibitors, zymogen activation and $\mathrm{pH}$. In Proteolysis in Cell Functions, Biomedical and Health Research, vol. 13, pp. 128-136 [VK Hopsu-Havu, $\mathrm{M}$ Jarvinen and $\mathrm{H}$ Kirschke, editors]. Turku: IOS Press.

31. Richter C, Tanaka T \& Yada RY (1998) Mechanism of activation of the gastric aspartic proteinases: pepsinogen, progastricsin and prochymosin. Biochem J 335, 481-490

32. Dubey VK, Pande M, Singh BK, et al. (2007) Papain-like proteases: applications of their inhibitors. Afr J Biotechnol 6, 1077-1086.

33. Kwiatek MA, Menne D, Steingoetter A, et al. (2009) Effect of meal volume and calorie load on postprandial gastric function and emptying: studies under physiological conditions by combined fiber-optic pressure measurement and MRI. Am J Physiol Gastrointest Liver Physiol 297, G894-G901.

34. Brener W, Hendrix TR \& McHugh PR (1983) Regulation of the gastric emptying of glucose. Gastroenterology $\mathbf{8 5}, 76-82$.
35. French SJ \& Read NW (1994) Effect of guar gum on hunger and satiety after meals of differing fat content: relationship with gastric emptying. Am J Clin Nutr 59, 87-91.

36. Gregory PC, McFadyen M \& Rayner DV (1995) Control of gastric emptying in the pig: influence of cholecystokinin, somatostatin and prokinetic agents. Exp Physiol 80, 159-165.

37. Schwizer W, Borovicka J, Kunz P, et al. (1997) Role of cholecystokinin in the regulation of liquid gastric emptying and gastric motility in humans: studies with the CCK antagonist loxiglumide. Gut 41, 500-504.

38. Montoya CA, Hindmarsh JP, Boland MJ, et al. (2011) Actinidincontaining kiwifruit extract enhances the stomach protein digestion of some dietary proteins in rats. In Proceedings of the Nutrition Society of Australia, vol. 35, p. 83.

39. Boirie Y, Dangin M, Gachon P, et al. (1997) Slow and fast dietary proteins differently modulate postprandial accretion. Proc Natl Acad Sci 94, 14930-14935. 